\title{
Multi-Purpose Dynamic Use of Right Subcostal Trocar in Laparoscopic Sleeve Gastrectomy: Retrospective Analysis of a Single Center Experience
}

\section{Laparoskopik Sleeve Gastrektomide Sağ Subkostal Trokarın Çok Amaçlı Dinamik Kullanımı: Tek Merkez Deneyiminin Retrospektif Analizi}

\author{
Hakan Seyit ${ }^{1} \oplus$, Halil Alış ${ }^{2}$ \\ ${ }^{1}$ Bakirkoy Dr. Sadi Konuk Training and Research Hospital, Department of General Surgery, Istanbul, Turkey \\ ${ }^{2}$ istanbul Aydın University, Department of General Surgery, Istanbul, Turkey
}

Received: 07 February 2020 / Accepted: 20 February 2020 / Publication date: 26 March 2020

Cite as: Seyit $\mathrm{H}$, Alış $\mathrm{H}$. Multi-purpose dynamic use of right subcostal trocar in laparoscopic sleeve gastrectomy: Retrospective analysis of a single center experiencee. Med J Bakirkoy 2020;16(1):40-3.

\section{ABSTRACT}

Objective: It is important to prevent exploration difficulties caused by the presence of fat and hypertrophic liver in obese patients and provide a good surgical field of vision. Recently, various liver retraction techniques have been described for laparoscopic procedures. We aimed to assess outcomes of a multi-purpose dynamic use of right subcostal trocar in laparoscopic sleeve gastrectomy.

Method: All patients who underwent laparoscopic sleeve gastrectomy from January 2016 to December 2017 were determined prospectively. The data were retrospectively reviewed.

Results: Five hundred and seventy-six patients were included in the study. Average age was 38.9 years, average body weight $130.8 \mathrm{~kg}$ and average body mass index (BMI) $47.4 \mathrm{~kg} / \mathrm{m}^{2}$. Complications such as bleeding, leakage and stenosis were observed in 6,7 and 6 patients, respectively. There were no significant change of the serum liver enzymes in both preoperative and postoperative periods. No additional retractor was required for liver retraction in any of the cases. None of our patients experienced any complications related to the methods described in the perioperative period.

Conclusion: Right subcostal trocar in laparoscopic sleeve gastrectomy for liver retraction can be successfully used without risks of postoperative morbidity and clear inspection of the surgical field with traction of the respective area. There is a need for long-term outcomes.

Keywords: bariatric surgery, laparoscopic surgery, liver retraction, sleeve gastrectomy

ÖZ

Amaç: Obez hastalarda yağ ve hipertrofik karaciğerin varlığından kaynaklanan araştırma zorluklarını önlemek ve iyi bir görüş alanı sağlamak önemlidir. Son zamanlarda, laparoskopik prosedürler için çeşitli karaciğer retraksiyon teknikleri tanımlanmıştır. Biz, laparoskopik sleeve gastrektomide sağ subkostal trokarın çok amaçı kullanımının sonuçlarını değerlendirmeyi amaçladık.

Yöntem: Ocak 2016 ve Aralık 2017 tarihleri arasında laparoskopik sleeve gastrektomi uygulanan tüm hastalar prospektif olarak belirlendi. Veriler geriye dönük olarak incelendi.

Bulgular: Beş yüz yetmiş altı hasta dahil edildi. Ortalama yaş 38.9 idi. Ortalama vücut ağırlığı 130.8 kg ve ortalama vücut kitle indeksi (VKi) 47.4 kg. Kanama, kaçak ve darlık gibi komplikasyonlar sırasıyla 6,7 ve 6 hastada gözlendi. Preoperatif ve postoperatif dönemde serum karaciğer enzimlerinde anlamlı bir değişiklik olmamıştır. Hiçbir olguda karaciğer retraksiyonu için ek retraktör gerekmedi. Peroperatif dönemde tarif edilen yöntemle ilgili komplikasyon görülmedi.

Sonuç: Karaciğer retraksiyonu için laparoskopik sleve gastrektomide sağ subkostal trokar kullanımı postoperatif morbidite riski olmadan ve ilgili alanın traksiyonu ile açık görüş başarıyla tamamlanabilir. Uzun vadeli sonuçlara ihtiyaç vardır.

Anahtar kelimeler: bariatrik cerrahi, laparoskopik cerrahi, karaciğer retraksiyonu, sleeve gastrektomi 


\section{INTRODUCTION}

Many bariatric procedures are routinely performed laparoscopically. A major challenge during surgery is the inability to achieve adequate inspection of the surgical field due to interference of the liver, especially during upper gastrointestinal surgery. It is important to overcome this challenge, as it is essential to prevent exploration difficulties caused by the presence of fat and hypertrophic liver in obese patients and provide a good field of vision. Recently, various liver retraction techniques have been described for laparoscopic procedures such as cholecystectomy and stomach resection ${ }^{(1)}$. Although mechanical retractors have traditionally been used to retract the liver, their use necessitates additional trocar entry. In response, new techniques have been developed in which the retractors are placed intracorporeally ${ }^{(1-4)}$. However, none of them has become known as a standard technique because each has advantages and disadvantages.

The aim of this study is to assess outcomes of a multi-purpose dynamic use of right subcostal trocar in laparoscopic sleeve gastrectomy (LSG) by emphasizing weight loss and complications.

\section{MATERIALS and METHODS}

The study included 576 patients with LSG performed from January 2016 to December 2017. The study was permitted by the local ethics committee. Prospectively-collected patient data were retrospectively reviewed.

Inclusion criteria were as follows:age 18 -65 years, baseline body mass index (BMI) $40 \mathrm{~kg} / \mathrm{m} 2$ or BMI of $35 \mathrm{~kg} / \mathrm{m}^{2}$ in the presence of additional comorbidity and failure of conservative treatment for 2 years.

Preoperatively gender, age, $\mathrm{BMI}\left(\mathrm{kg} / \mathrm{m}^{2}\right)$ and weight $(\mathrm{kg})$, duration of surgery ( $\mathrm{min})$, and hospitalization, and postoperative complications were collected. Follow-up of patients was performed at 1, 6, 12, months after surgery. Liver function tests were performed by measuring the levels of serum alanine aminotransferase (ALT) and aspartate aminotransferase (AST) preoperatively and on first postoperative day. Weight loss(kg), BMI variation, percentage of excessive weight loss (EWL) and mortality were recorded.

\section{Surgical technique}

After placing the patient in the 30 reverseTrendelenburg position, we directly inserted a 10-mm trocar approximately $10 \mathrm{~cm}$ below the xiphoid process and $1 \mathrm{~cm}$ lateral to the midline. Then we inserted four trocars ( $5 \mathrm{~mm}$ to the right subcostal, 15 $\mathrm{mm}$ to the right midclavicular $5 \mathrm{~mm}$ to the left subclavicular, and $5 \mathrm{~mm}$ to the left subcostal line) into the abdomen under direct vision, forming a concave cocnfiguration. By inserting a laparoscopic $5 \mathrm{~mm}$ atraumatic grasper through the right subcostal trocar, we achieved superior traction of the stomach along the large curvature, which resulted in retraction of the liver (Figure 1). The addition of this traction maneuver mobilized greater curvature of the stomach by transecting the gastrocolic ligament and short gastric vessels. With the aid of the same instrument, we held the free side of the stomach fundus to achieve traction toward the liver and upper abdominal wall (Figure 2). With this maneuver, we achieved both retraction of the liver and exploration of posterior wall of the stomach $i$ and also left hand of the surgeon was freed.

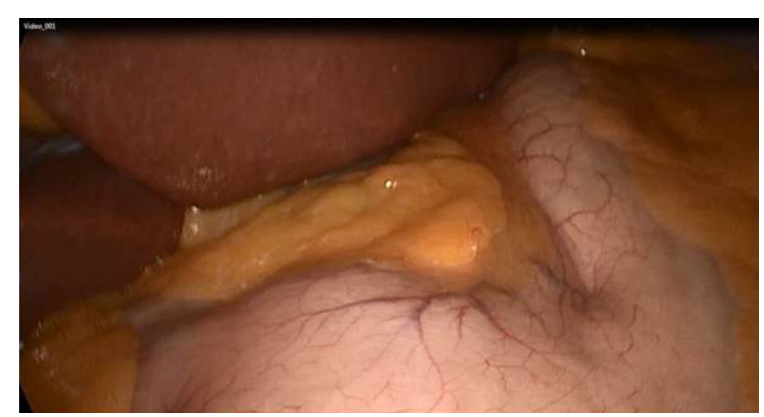

Figure 1. Superior traction of the stomach along the large curvature.

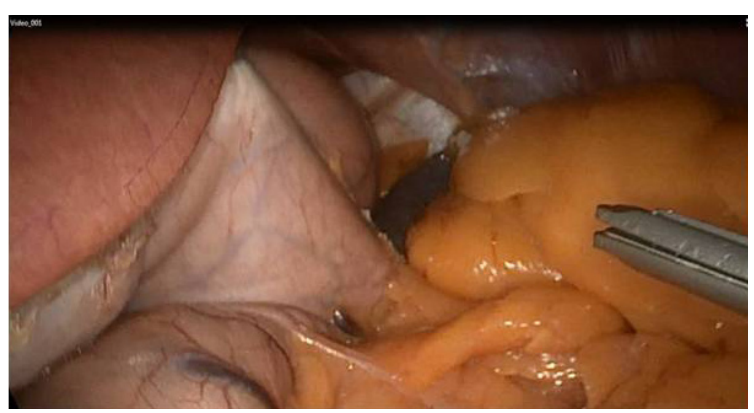

Figure 2. Traction of fundus and dissection of hiatus. 
Under wide and clear vision, we performed hiatus dissection until the left crus was exposed and the stomach fundus was completely released. To release the distal part of stomach, we held the free side of the antrum in a similar manner and tracted it to reveal the hepatoduodenal ligament, duodenum, and distal part of the stomach. Then we mobilized the distal part of the stomach up to the pylorus (Figure 3). Under the guidance of 36-F bougie, we introduced an articulating linear cutting stapler (suture length $60 \mathrm{~mm}$, staple height $4.8 \mathrm{~mm}$; Endo GIATM, Covidien, Norwalk, CT, USA) starting $2 \mathrm{~cm}$ proximal to the pylorus. During this step we used the right subcostal trocar for liver retraction (Figure 4). After the first 2 fires, we used $3.5 \mathrm{~mm}$ stapler loads (EndoGIATM, Covidien, Norwalk, CT) to complete the stomach dissection along the bougie up to the angle of His. After the stomach was completely separated, we checked the stapler line and the separated omentum for hemostasis. All procedures were performed fully laparoscopically by two experienced surgeons using the same standard technique. For all techniques, anastomosis or stapler lines were checked with methylene blue to inspect anastomotic leaks.

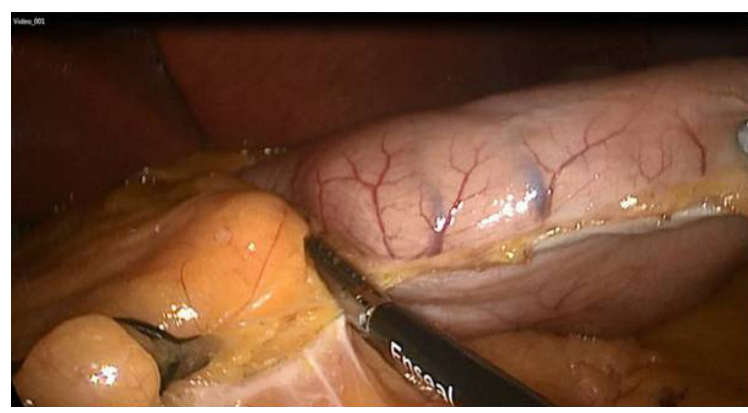

Figure 3. Traction of antrum and release of the distal stomach.



Figure 4. Retraction of the liver during stapling.

\section{RESULTS}

Of the 576 consecutive patients we examined, 437 were female $(75.8 \%)$. The mean age was 38.9 years, the mean body weight $130.8 \mathrm{~kg}$ (range 94-240), and mean body mass index (BMI) $47.4 \mathrm{~kg} / \mathrm{m} 2$ (Table 1). Mean duration of surgery was 75 minutes and hospital stay 4 days. Complications such as bleeding, leakage and stenosis are shown in Table 2.

Table 1. Demographic data in the preoperative period.

\begin{tabular}{lcc}
\hline Variable & Value & (Interval) \\
\hline Gender (male/female) & $139 / 437$ & - \\
Age (years) & 38,9 & $(19-63)$ \\
Weight $(\mathrm{kg})$ & 130,8 & $(94-240)$ \\
BMI $\left(\mathrm{kg} / \mathrm{m}^{2}\right)$ & 47,4 & $(40-106)$ \\
\hline
\end{tabular}

BMI: body mass index

Table 2. Surgery outcomes of patients.

\begin{tabular}{|c|c|c|}
\hline \multicolumn{2}{|l|}{ Variable } & Value \\
\hline \multicolumn{2}{|c|}{ Operation time (minutes) } & $75.22 \pm 21.65$ \\
\hline \multicolumn{2}{|c|}{ Hospital stay (days) } & $4.07 \pm 1.50$ \\
\hline $\begin{array}{l}\text { Complications } \\
\text { (n) }\end{array}$ & $\begin{array}{c}\text { Leak } \\
\text { Hemorrhage } \\
\text { Stenosis }\end{array}$ & $\begin{array}{l}7 \\
6 \\
6\end{array}$ \\
\hline
\end{tabular}

BMI: body mass index

There were no significant change of the serum liver enzymes during both preoperative and postoperative periods ( $p>0.05$ ) (Table 3 ). The mean weight loss in the postoperative one-year period was 43.8 kilograms (22-80). Postoperatively, mean BMI and EWL \% values are indicated in Table 4. In 105 (87.5\%) patients, we achieved satisfactory EWL \% values. There was no mortality in study group.

Table 3. Preoperative and postoperative level of serum liver enzymes.

\begin{tabular}{lccc}
\hline & Preoperative & Postoperative & P \\
\hline ALT (IU/L) & $21.8 \pm 16.7$ & $28.2 \pm 13.7$ & 0.84 \\
AST (IU/L) & $25.2 \pm 17.6$ & $31.8 \pm 22.1$ & 0.91 \\
\hline
\end{tabular}

ALT: alanine aminotransferase, AST: aspartate aminotransferase

Table 4. Postoperative follow-up parameters.

\begin{tabular}{lc}
\hline Variable & Value \\
\hline Weight loss $(\mathrm{kg})$ & $43.8(22-80)$ \\
$\mathrm{BMI}\left(\mathrm{kg} / \mathrm{m}^{2}\right)$ & $32.1(23-55)$ \\
EWL $(\%)$ & $62.9(30-101)$ \\
\hline
\end{tabular}

BMI: body mass index, EWL: excessive weight loss 
We did not require any additional retractors to assist with liver retraction during any of the operations. None of our patients experienced any complications related to the methods described in the perioperative period nor elevations in liver function parameters in the postoperative period.

\section{DISCUSSION}

Unimpeded observation of the small and large curvatures of the stomach as well as the hiatus is necessary for safe and effective performance of all bariatric procedures. For this purpose, Nathanson, fan-shaped, and snake mechanical retractors of various shapes and sizes have been used in laparoscopic upper gastrointestinal and bariatric surgeries to retract the left lobe of the liver and provide a better field of view ${ }^{(1)}$. Although mechanical excision through the subxiphoid approach provides a good visual field, it has potential side effects, including postoperative pain, wound complications, and iatrogenic liver injury ${ }^{(1)}$.

Several alternative methods of laparoscopic surgery are described in the literature. In the Istanbul technique, a Penrose drain attached to two silk sutures is placed under the lateral segment of the liver to serve as a "hammock" (2). In another technique two $4 \times 4$ gauze pads are folded and then threaded using a 2-0 polypropylene monofilament suture to create a makeshift traumatic support for liver suspension ${ }^{(3)}$. Although both techniques provide non-traumatic hanging of the liver, the hammock and gauze pads must be manually made, lengthening surgical time. In a technique used to hang the liver using the percutaneous method, a $15 \mathrm{~cm}$ Veress needle covered with a 16- to 18-French nasogastric tube or drainage tube is inserted into the abdomen from the subxiphoid area to retract liver. Although this method reduces the need for additional incision, trocars, and retractors, it fails to provide adequate retraction of a hypertrophic liver ${ }^{(4)}$.

Based on our clinical experience, we developed a new method of retraction in laparoscopic sleeve gastrectomy (LSG) using a multi-purpose right subcostal trocar. Use of this method allows dynamic retraction of the liver and traction of the stomach during LSG surgery. When used with a laparoscopic $5 \mathrm{~mm}$ atraumatic grasper, inserted in the right sub- costal region and manipulated differently at each step of surgery, our method permits clear inspection of the hiatus.

Use of our multi-purpose subcostal trocar technique overcomes these challenges in gfavour of successful LSG surgery. One advantage is that it achieves liver retraction in patients with a BMl as high as $106 \mathrm{~kg} / \mathrm{m} 2$ with severe hepatomegaly, which has resulted in successful surgery in our patients with this condition. Contrary to the results of Tamhankar et al. ${ }^{(5)}$, use of our method prevents liver deterioration by achieving dynamic liver retraction via application of brief periods of pressure to different parts of the liver, which is enabled by the ability to maneuver the surgical instrument as necessitated for this reason, our patients did not experience any change in liver function, as evidenced by liver function tests performed in the early postoperative period. It facilitates manipulation of the instrument during repositioning, so any additional trocars for liver retraction are not required decreasing the risk of intraoperative complications.

In conclusion, by allowing us to achieve liver retraction at every stage of surgery, permitting clear inspection with traction of the respective area, use of our method facilitates more efficient and safe dissection and LSG surgery.

Ethics Committee Approval: Bakirkoy Dr. Sadi Konuk Training and Research Hospital, Clinical Research Ethics Committee approval was received (2018-34).

Conflict of Interest: Authors have no conflict of interest. Funding: Authors have no financial support.

Informed Consent: This article is a retrospective study.

\section{REFERENCES}

1. Goel R, Shabbir A, Tai CM. Randomized controlled trial comparing three methods of liver retraction in laparoscopic Roux-en-Y gastric bypass. Surg Endosc. 2013;27:679-84.

https://doi.org/10.1007/s00464-012-2438-6

2. Hamzaoglu I, Karahasanoglu T, Aytac E, Karatas A, Baca B. Transumbilical totally laparoscopic single-port Nissen fundoplication: A new method of liver retraction: The Istanbul technique. J Gastrointest Surg. 2010;14:1035-9. https://doi.org/10.1007/s11605-010-1183-1

3. Woo Y, Hyung WJ, Kim HI, Obama K, Son T, Noh SH. Minimizing hepatic trauma with a novel liver retraction method: A simple liver suspension using gauze suture. Surg Endosc. 2011;25:3939-45. https://doi.org/10.1007/s00464-011-1788-9

4. Gianni S, De Luca M, Oscar B, et al. Veress needle: A simple liver retraction technique for lap band positioning in (single incision laparoscopic technique) SILS. Obes Surg. 2012;22:190-1. https://doi.org/10.1007/s11695-011-0383-4

5. Tamhankar AP, Kelty CJ, Jacob G. Retraction-related liver lobe necrosis after laparoscopic gastric surgery. JSLS. 2011;15:117-21. https://doi.org/10.4293/108680811X13022985131651 